\title{
A study on the needs to improve Korea abattoir's critical control point of HACCP system
}

\author{
Seongjoon Kim, Kwanghoon Choi, Donghoon Myung, Hangsung Chung, Sukwon Kim, Nonghoon Choe* \\ College of Veterinary Medicine, Konkuk University, Seoul 05029, Korea
}

\begin{abstract}
These days abattoirs' hygiene of Korea is regulated by Hazzard Analysis Critical Control Point (HACCP). Although 20 years have been left since first HACCP was adjusted in Korea, $12 \%$ of abattoirs got inconsistence on evaluations. Food poisoning caused by bacteria feces like pathogenic Escherichia coli and Salmonella has not decreased. These bacteria on meat crosscontaminate at the abattoir. Therefore, field verification of abattoir's critical control point (CCP) and experiments to find alternative ways of the $\mathrm{CCP}$ were conducted. The aerobic bacteria were measured before and after high-pressure water based washing process set as CCP in most abattoirs. Four parts of cattle carcasses were selected to apply sponge-swab method. The effects were $<1$ log reduction which is not significant. Lactic acid (LC), chlorine dioxide $\left(\mathrm{ClO}_{2}\right)$ and slightly acidic electrolyzed water (SAEW) were used to measure the effect of reducing bacteria on beef by the different time. $\mathrm{LC}$ has 1.24-2.02 log reduction for aerobic bacteria. $\mathrm{ClO}_{2}$ has 1.44-1.96 log reduction for aerobic bacteria. SAEW has 1.1-1.91 log reduction for aerobic bacteria. There was significant difference according to concentrations $(p<0.05)$. This study presents legitimacy for hygiene improvement of CCP by field verification. In addition, chemical disinfectants that can be mechanically applied have better reduction effects of high-pressure washing.
\end{abstract}

Keywords: abattoirs, South Korea, Hazard Analysis and Critical Control Points, disinfectants

*Corresponding author

Nonghoon Choe

College of Veterinary Medicine, Konkuk University, 120 Neungdong-ro, Gwangjin-gu, Seoul 05029, Korea

Tel: $+82-2-450-3709$

Fax: +82-2-454-3709

E-mail: nojamaji@hanmail.net

ORCID

Seongjoon Kim

https://orcid.org/0000-0001-5505-2957

Kwanghoon Choi

https://orcid.org/0000-0002-0580-250X

Donghoon Myung

https://orcid.org/0000-0003-3251-6813

Hansung Chung

https://orcid.org/0000-0003-4405-7511

Sukwon Kim

https://orcid.org/0000-0003-1606-719X

Nonghoon Choe

https://orcid.org/0000-0002-8809-6064

Conflict of Interest

The authors declare no conflict of interest.

Received: December 27, 2019

Revised: May 6, 2020

Accepted: June 4, 2020

\section{Introduction}

Meat is highly prone to contamination by various bacteria, such as Salmonella, Listeria, Campylobacter, Clostridium perfringens, Escherichia coli O157:H7, and Yersinia. Of these, the greatest threat to public health is E. coli $\mathrm{O} 157: \mathrm{H} 7$, which is derived from feces and is typically found in the intestine of cows [1]. So high-pressure water based washing method that is used the majority of abattoirs in Korea is set as a critical control point (CCP). This method controls contamination in meat through water pressure and time. However, using only water pressure and time involves many disadvantages. Organic matters on the meat are often scattered due to the high-pressure, and these scattered organic matters can give way to secondary contamination. Moreover, if time, volume of water, pressure, temperature, and various other conditions are not met, the microorganism reduction effect drastically decreases, which means that contamination in one area of meat may quickly spread throughout other areas of meat [2-4]. Other various methods have been proposed to control meat contamination through results from previous studies. However, these methods cannot be used if they are not economically feasible. $82 \%$ of abattoirs in Korea replied that their business conditions are difficult or average, indicating that most abattoirs in Korea face financial issues [5].

Therefore, this study will evaluate the effectiveness of high-pressure water based washing that is used in most abattoirs. Also, the study of reduction effect of approved chemical disinfectants was conducted to replace CCP.

\section{Materials and Methods}

\section{Verification of high-pressure water based washing method \\ Location}

This study was performed a t Livestock Process Complex in Gyeonggi-do. The abattoir processed up to 10 cattles and 1,700 pigs on average per day. 


\section{Swab}

Total 25 carcasses were collected in 5 days. Collecting site was high-pressure washing process defined as CCP on abattoir. Whirl-pak (Nasco, USA) was used to collect samples. Sterilized sponges soaked with $20 \mathrm{~mL} 0.1 \%$ (W/V) peptone water (PW; peptone, Difco, USA) were used to swab. Brisket, front-leg, flank and neck were collected $\left(100 \mathrm{~cm}^{2}\right)$. To avoid overlapped sampling and accuracy, sampling was performed at the left side of carcasses. After collecting samples, samples were kept in the refrigerator until performing microbiological examination. Microbiological examinations were performed within $20 \mathrm{~h}$ after sampling.

\section{Microbial testing}

The $20 \mathrm{~mL}$ of $0.1 \% \mathrm{PW}$ was inserted to Whirl paks sampling cattle carcass to make total volume as $40 \mathrm{~mL}$. Whirl paks were homogenized for $30 \mathrm{sec}$ using shaker. After homogenization, $1 \mathrm{~mL}$ was transported from whirl-pak to AC petri film $\left(3 \mathrm{M}^{\mathrm{TM}}\right.$, USA). All films were incubated at $36^{\circ} \mathrm{C}$ for $48 \mathrm{~h}$.

Decontamination effects of chlorine dioxide $\left(\mathrm{ClO}_{2}\right)$, lactic acid (LC) and slightly acidic electrolyzed water (SAEW) for different concentration on bacteria inoculated beef

\section{Bacteria culture}

Aerobic bacteria were used. Aerobic bacteria were collected from carcass not taking high-pressure washing. Sampling points were brisket, flank and rump $\left(100 \mathrm{~cm}^{2}\right)$. Samples were transported laboratory being chilled. The $1 \mathrm{~mL}$ was transported from whirl-pak to nutrient broth (NB; Oxoid, USA) to proliferate. After incubating at $37^{\circ} \mathrm{C}$ for $24 \mathrm{~h}, 1 \mathrm{~mL}$ of incubated NB was transferred to another NB. These cycles were repeated until performing experiment because of the cell activations.

\section{Disinfectants}

LC (Tokyo Chemical Industry Co., Ltd., Japan) was carried in powder form. LC powder was dissolved in water at $55^{\circ} \mathrm{C}$ before conduct experiment. Concentration of LC was $1 \%, 2 \%, 3 \%(\mathrm{~W} / \mathrm{V})$. Slightly acidic electrolyzed water (SAEW; Cosmic-Round Korea Co., Ltd., Korea) was carried in the aqueous form. SAEW was diluted in water at $55^{\circ} \mathrm{C}$ before conduct experiment. Concentration of SAEW was 10 , 20 and 30 ppm. $\mathrm{ClO}_{2}$ (Furgo-farm Co., Ltd., Korea) was carried in aqueous form. $\mathrm{ClO}_{2}$ was diluted in water at $55^{\circ} \mathrm{C}$ before conducting experiment. Concentration of $\mathrm{ClO}_{2}$ was 10, 20 and $40 \mathrm{ppm}$. Solutions were prepared using deionized water.

\section{Application methods}

To mimic abattoir's environment, the applied system was made. Beef was broken into pieces aseptically by $5 \mathrm{~g}$ in clean bench with sterilized scissor and forceps. Beef was transferred to small petri-dishes $(35.00 \times 10.00 \mathrm{~mm})$ with a hole of the side. The hole at petri-dish was made for letting disinfectants get out. If disinfectant couldn't get out, it would affect the results of experiment. The $0.5 \mathrm{~mL}$ of $\mathrm{NB}$ which contains aerobic bacteria from the abattoir was inoculated. The inoculum density was adjusted to 0.010 absorbance units at $600 \mathrm{~nm}$ using a micro ELISA plate reader (SoftMax Pro, USA). The mean concentration of inoculated NB was 5.77 $\log$ colony forming unit (CFU)/mL. There was 10 min attaching bacteria to beef. Five petri-dishes put into the chamber obliquely. Spray (Marolex Sp. Z o.o., Poland) containing disinfectants was put in front of chamber. Length of spray to petri-dishes was $20 \mathrm{~cm}$. Antimicrobial applications were sprayed for 5 or $10 \mathrm{sec}$. After being sprayed, wait $10 \mathrm{~min}$. To stop activating disinfectants, beef on the dishes was transferred to neutralization broth which contains $20 \%$ yeast extract (BD DIFCO, USA). Then the beef was shaken for 30 min on shaker.

\section{Microbial testing}

$1 \mathrm{~mL}$ was transported from neutralization broth to AC petri film $\left(3 \mathrm{M}^{\mathrm{TM}}\right)$. All films were incubated at $36^{\circ} \mathrm{C}$ for $48 \mathrm{~h}$.

\section{Statistical analysis}

The data is expressed as mean and standard deviation of the $\log _{10}$ value. Statistical analysis was performed by GraphPad Prism 5.01(GraphPad Software Inc., USA). Two-way analysis of variance and Bonferroni post tests are used to analyze. Significant differences were defined as $p<0.05$.

\section{Results}

\section{Verification of high-pressure water based washing method}

Before high-pressure washing, the contamination levels of flank, brisket, front leg and neck are 2.05, 3.63, 3.23 and $2.85 \log \mathrm{CFU} / \mathrm{cm}^{2}$, respectively. After high-pressure washing, the contamination levels of flank, brisket, front leg and neck are 2.18, 2.63, 2.38 and $2.16 \log \mathrm{CFU} / \mathrm{cm}^{2}$, respectively (Fig. 1). Average contamination level of carcasses at before high-pressure washing is $2.94 \log \mathrm{CFU} / \mathrm{cm}^{2}$. Average contamination level of carcasses at after high-pressure washing is $2.34 \log \mathrm{CFU} / \mathrm{cm}^{2}$. There is significant $\log$ reduction at brisket, front leg and neck. Contamination levels of brisket, front leg and neck after high-pressure washing were significantly reduced by $1,0.86$ and $0.68 \log \mathrm{CFU} / \mathrm{cm}^{2}$, respectively, compared with those before high-pressure washing $(p<0.05)$. However, in case of flank, there is no significant reduction between before and after high-pressure washing $(p>0.05)$. On the contrary, contamination level of after highpressure washing is slightly increased than that of before high-pressure washing.

Decontamination effects of $\mathrm{ClO}_{2}, \mathrm{LC}$ and SAEW for different concentration on bacteria inoculated beef

Application of LC for $5 \mathrm{sec}$ significantly reduce aerobic bacteria by $4.47,4.22$ and $3.75 \log \mathrm{CFU} / \mathrm{mL}$ for treatment 


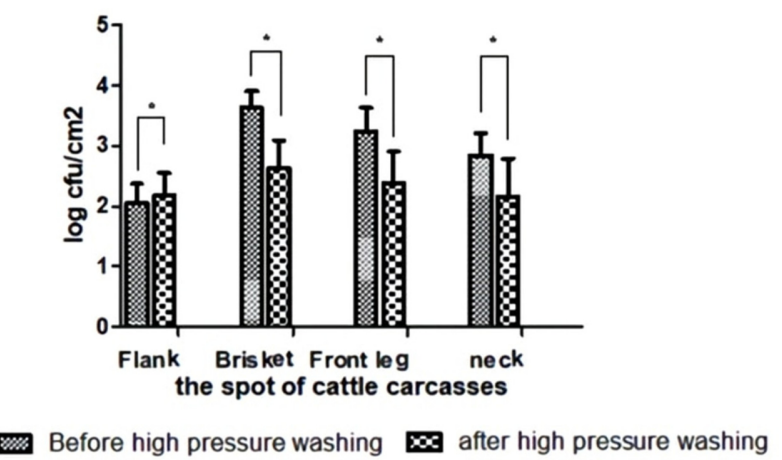

Fig. 1. The contamination level of aerobic bacteria before/after high-pressure water based washing. Four spots (flank, brisket, front leg, neck) of cattle carcasses are collected $(n=25)$. All data are expressed as mean $\pm \mathrm{SD}$.

${ }^{*} p<0.05$.

concentration of $1 \%, 2 \%$ and $3 \%$, respectively. Application of LC for $10 \mathrm{sec}$ significantly reduce aerobic bacteria by 4.53, 4.12 and $3.84 \log \mathrm{CFU} / \mathrm{mL}$ for treatment concentration of $1 \%, 2 \%$ and $3 \%$, respectively. $\mathrm{ClO}_{2}$ at the concentration of 10,20 and $40 \mathrm{ppm}$ is significantly reduced aerobic bacteria by $4.24,4.21$ and $3.53 \log \mathrm{CFU} / \mathrm{mL}$ after treatment for $5 \mathrm{sec}$, respectively, and by $4.25,4.15$ and $3.54 \log \mathrm{CFU} / \mathrm{mL}$ after treatment for $10 \mathrm{sec}$, correspondingly. In addition, SAEW at the concentration of 10,20 and $40 \mathrm{ppm}$ was significantly reduced aerobic bacteria by $4.66,4.52$ and $3.88 \log \mathrm{CFU} / \mathrm{mL}$ after treatment for $5 \mathrm{sec}$, respectively, and by $4.64,4.49$ and $3.86 \log \mathrm{CFU} / \mathrm{mL}$ after treatment for $10 \mathrm{sec}$, correspondingly. There are no significant difference between treatment time $(p>0.05)$. However, when it comes to concentration there are significant reduction. $(p<0.05)$.

\section{Discussion}

The reduction of aerobic bacteria on chest, front leg and neck after high-pressure washing was 1.0, 0.86 and $0.68 \mathrm{log}$ $\mathrm{CFU} / \mathrm{mL}$, respectively, compared with those before highpressure washing (Fig. 1). According to the previous study, it is not very effective on a small number of common bacteria, coliform, and E. coli cells [6]. Also coincide with other studies reporting that high-pressure washing with only water offers an extremely low bacteria reduction rate and even causes contamination on the surface of other pieces of meat $[2-4,7]$. Moreover, the $\log$ reduction value was negative for flanks, which demonstrates that microorganism contamination increased after high-pressure washing than before. In the study that was conducted on a large-scale abattoir, the level of microorganismal contamination increased from $0.78 \mathrm{log}$ $\mathrm{CFU} / \mathrm{cm}^{2}$ to $1.01 \log \mathrm{CFU} / \mathrm{cm}^{2}$, revealing that the method acts to redistribute the bacteria than to remove them [8]. These results show the methods used in abattoir are not quite effective for meat hygiene. Therefore, the alternative methods using disinfectants should be considered. LC has 1.24-
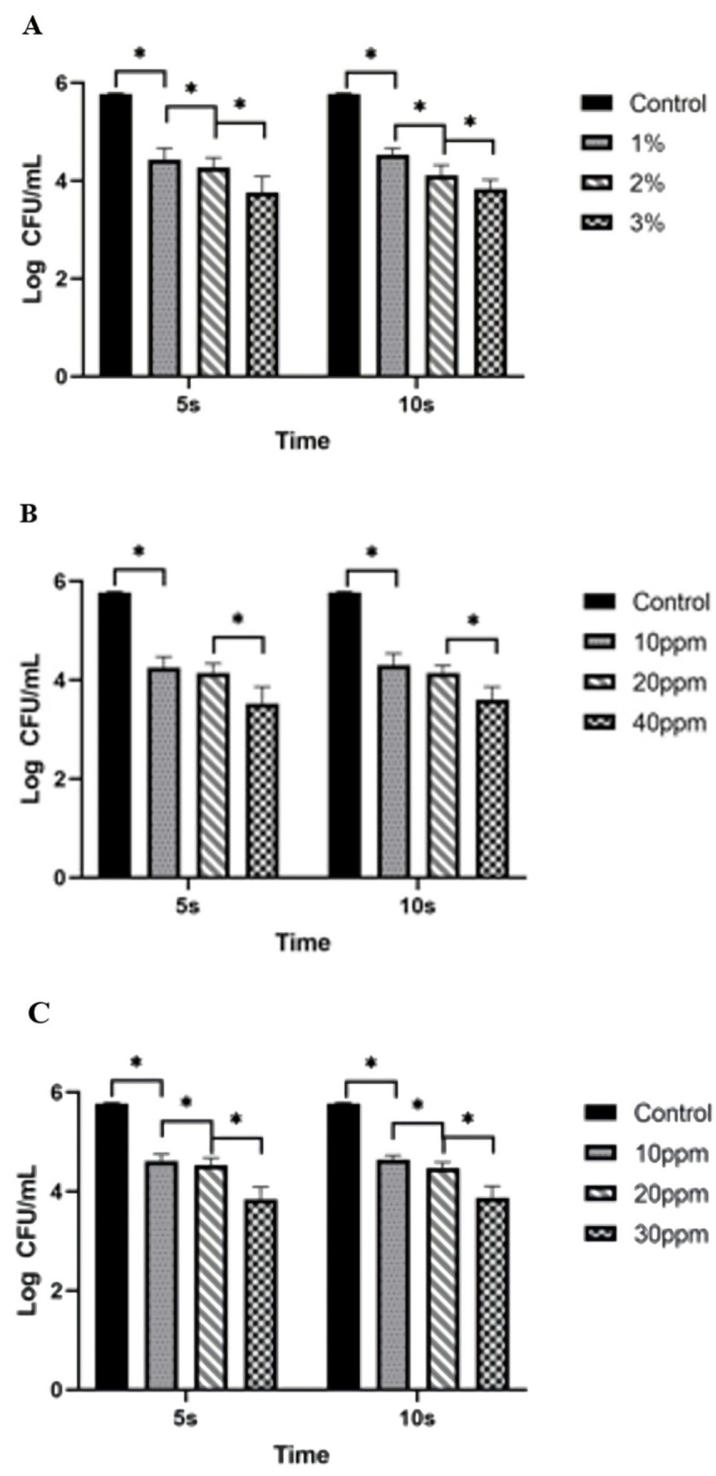

Fig. 2. The decontamination effects of lactic acid (A), chlorine dioxide (B), slightly acidic electrolyzed water (C) regarding aerobic bacteria on beef samples $(n=15)$. All data are expressed as mean $\pm \mathrm{SD}$. ${ }^{*} p<0.05$.

$2.02 \mathrm{log}$ reduction for aerobic bacteria (Fig. 2). This coincides with the results of previous studies reporting that $2 \%$ LC sprayed onto beef head for $26 \mathrm{sec}$ led to $1.52 \mathrm{log}$ reduction in microorganismal count, with $2 \%$ LC sprayed on beef resulting in $1.6 \mathrm{log}$ reduction in microorganismal count $[9,10]$. Moreover, $2 \%$ LC applied for $15 \mathrm{sec}$ on meat inoculated with $E$. coli was found to result in 1.5-2.2 log reduction in $E$. coli count [11]. Similarly, when LC was sprayed in the abattoir, there was a $0.9-2.3 \log$ reduction in aerobic bacteria [12]. Another study also reported an improvement in the storage quality of meat to which $\mathrm{LC}$ was applied [13]. $\mathrm{ClO}_{2}$ has $1.44-1.96 \log$ reduction for aerobic bacteria. This is similar to a previous study reporting that when $10 \mathrm{ppm}$ of $\mathrm{ClO}_{2}$ 
was used, it resulted in $\geq 1.53 \log$ reduction [14], as well as another study reporting that when $\mathrm{ClO}_{2}$ was used on chicken carcasses, significant reduction was found even at concentrations below $10 \mathrm{ppm}[15,16]$. However, when $800 \mathrm{ppm}$ of $\mathrm{ClO}_{2}$ was used on beef inoculated with $E$. coli, the result did not exceed $1.3 \log$ reduction in E. coli count [14]. The differences in reduction of this study compared to the previously mentioned may be due to different inoculation methods, as well as initial microbial concentration, contact time, type of fruit, disinfection system, disinfectant forms, and enumeration method. According to a previous study, application of $\mathrm{ClO}_{2}$ for $1 \mathrm{~min}$ or less did not lead to significant reduction and this shows the importance of long contact time [12]. SAEW has 1.1-1.91 log reduction for aerobic bacteria. According to previous studies, $20 \mathrm{ppm}$ of SAEW resulted in $1.5 \mathrm{log}$ reduction of aerobic bacteria, and $40 \mathrm{ppm}$ of SAEW showed a significant reduction in mesophilic bacteria in pork meat $[17,18]$. However, when meat was treated with SAEW for 5 min using the dipping method, aerobic bacteria reduced from $3.06 \log$ CFU to $2.28 \log$ CFU [19]. Free chlorine concentration is the most important factor that determines the sterilization effect of SAEW, it is most effective at $\mathrm{pH}$ between 6.0 to 7.5 [20]. Therefore, the results may differ due to differences in PH caused by technicalities.

These results indicate that application of chemical disinfectants can be alternative method to get over high-pressure and time which is disadvantages of high-pressure water based washing. Results indicate chemical disinfectants show constant effects not greatly affected by low pressure and application time, and show higher decontamination efficacy than high-pressure washing method. The results could be serve as a basis for other decontamination methods on abattoir model.

\section{Acknowledgments}

This work was supported by Korea Institute of Planning and Evaluation for Technology in Food, Agriculture, Forestry and Fisheries (IPET) through Animal Disease Management Technology Development Program, funded by Ministry of Agriculture, Food and Rural Affairs (MEFRA) (316045-3).

\section{References}

1. Koohmaraie M, Arthur TM, Bosilevac JM, Guerini M, Shackelford SD, Wheeler TL. Post-harvest interventions to reduce/eliminate pathogens in beef. Meat Sci 2005;71:79-91.

2. Bell RG. Distribution and sources of microbial contamination on beef carcasses. J Appl Microbiol 1997;82:292-300.

3. Jericho KW, Bradley JA, Kozub GC. Microbiologic evaluation of carcasses before and after washing in a beef slaughter plant. J Am Vet Med Assoc 1995;206:452-455.

4. Reagan JO, Acuff GR, Buege DR, Buyck MJ, Dickson JS, Kastner CL, Marsden JL, Morgan JB, Nickelson R 2nd, Smith GC, Sofos JN. Trimming and washing of beef carcasses as a method of improving the microbiological quality of meat. J Food Prot 1996;59:751-756.
5. Ji IB, He D, Kim HJ, Seo GC, Ju JS. Mid to Long-Term Development Strategy for Slaughtering Industry. pp. 33-35, Korea Rural Economic Institute, Naju, 2015.

6. Gill CO, Landers C. Microbiological effects of carcass decontaminating treatments at four beef packing plants. Meat Sci 2003;65:1005-1011.

7. Yalçin S, Nizamlioğlu M, Gürbüz Ü. Fecal coliform contamination of beef carcasses during the slaughtering process. $\mathrm{J}$ Food Saf 2001;21:225-231.

8. Yang X, Badoni M, Youssef MK, Gill CO. Enhanced control of microbiological contamination of product at a large beef packing plant. J Food Prot 2012;75:144-149.

9. Bosilevac JM, Nou X, Barkocy-Gallagher GA, Arthur TM, Koohmaraie M. Treatments using hot water instead of lactic acid reduce levels of aerobic bacteria and Enterobacteriaceae and reduce the prevalence of Escherichia coil $\mathrm{O} 157: \mathrm{H} 7$ on preevisceration beef carcasses. J Food Prot 2006;69:1808-1813.

10. Kalchayanand N, Arthur TM, Bosilevac JM, Brichta-Harhay DM, Guerini MN, Wheeler TL, Koohmaraie M. Evaluation of various antimicrobial interventions for the reduction of Escherichia coli $\mathrm{O} 157: \mathrm{H} 7$ on bovine heads during processing. J Food Prot 2008;71:621-624.

11. Dorsa WJ, Cutter CN, Siragusa GR. Effects of acetic acid, lactic acid and trisodium phosphate on the microflora of refrigerated beef carcass surface tissue inoculated with Escherichia coli O157: H7, Listeria innocua, and Clostridium sporogenes. J Food Prot 1997;60:619-624.

12. Prasai RK, Acuff GR, Lucia LM, Hale DS, Savell JW, Morgan JB. Microbiological effects of acid decontamination of beef carcasses at various locations in processing. J Food Prot 1991;54:868-872.

13. Echeverry A, Brooks JC, Miller MF, Collins JA, Loneragan $\mathrm{GH}$, Brashears MM. Validation of intervention strategies to control Escherichia coli $\mathrm{O} 157: \mathrm{H} 7$ and Salmonella typhimurium DT 104 in mechanically tenderized and brine-enhanced beef. J Food Prot 2009;72:1616-1623.

14. Cutter CN, Siragusa GR. Application of chlorine to reduce populations of Escherichia coli on beef. J Food Saf 1995; 15:67-75.

15. Lillard HS. Levels of chlorine and chlorine dioxide of equivalent bactericidal effect in poultry processing water. $\mathrm{J}$ Food Sci 1979;44:1594-1597.

16. Lillard HS. Effect on broiler carcasses and water of treating chiller water with chlorine or chlorine dioxide. Poult Sci 1980;59:1761-1766.

17. Aday MS. Application of electrolyzed water for improving postharvest quality of mushroom. Lebenson Wiss Technol 2016;68:44-51.

18. Koide S, Takeda JI, Shi J, Shono H, Atungulu GG. Disinfection efficacy of slightly acidic electrolyzed water on fresh cut cabbage. Food Control 2009;20:294-297.

19. Sheng X, Shu D, Tang X, Zang Y. Effects of slightly acidic electrolyzed water on the microbial quality and shelf life extension of beef during refrigeration. Food Sci Nutr 2018; 6:1975-1981.

20. Nan S, Yongyu LI, Baoming LI, Wang C, Cui X, Cao W. Effect of slightly acidic electrolyzed water for inactivating Escherichia coli 0157:H7 and Staphylococcus aureus analyzed by transmission electron microscopy. J Food Prot 2010;73: 2211-2216. 